\title{
PROPISCIN - A SAFE ANAESTHETIC FOR PIKEPERCH (SANDER LUCIOPERCA L.)
}

\author{
Maciej RoŻYŃSKI $^{1 *}$, Elżbieta ZIOMEK ${ }^{2}$, Krystyna DEMSKA-ZAKĘŚ $^{2}$, Agata KowALSKA $^{1}$ \\ and Zdzisław ZAKĘ́s ${ }^{1}$ \\ ${ }^{1}$ Department of Aquaculture, The Stanisław Sakowicz Inland Fisheries Institute, \\ ul. Oczapowskiego 10, 10-719 Olsztyn, Poland; ${ }^{2}$ Department of Ichthyology, \\ Faculty of Environmental Sciences, University of Warmia and Mazury, Olsztyn, Poland
}

(Received 15 December 2015; accepted 15 July 2016)

The aim of this work was to determine the impact of etomidate (Propiscin) dose $\left(1\right.$ and $\left.2 \mathrm{ml} \mathrm{l}^{-1}\right)$ and exposure time $(2$ and $10 \mathrm{~min})$ on the biochemical and haematological parameters of juvenile pikeperch (Sander lucioperca) [mean body length (Lc) $25.9 \mathrm{~cm}$; body weight (W) $189.9 \mathrm{~g}$ ] that were reared in a recirculating aquaculture system (RAS). Significant changes in the mean values of total protein, globulin, calcium, magnesium, and ammonia were noted in all groups immediately following exposure. The greatest changes in the haematological indicators were observed in groups subjected to 10-min exposure at both doses of the anaesthetic. The specimens from these groups had higher values for white blood cells (WBC), red blood cells (RBC), haemoglobin (HGB), haematocrit (HCT), and mean corpuscular volume (MCV). Statistically significant differences in these same parameters were also noted in the groups of fish exposed to the anaesthetic for $2 \mathrm{~min}$ at a dose of $2 \mathrm{ml} \mathrm{l}^{-1}$, but they were not as pronounced. Twenty-four $\mathrm{h}$ following exposure to etomidate, all blood parameters in the experimental groups were comparable to those of the control group. Etomidate can be recommended as a safe, effective anaesthetic for pikeperch.

Key words: Anaesthesia, biochemical blood indicators, etomidate, haematology, pikeperch

The application of anaesthetics is essential and quite common in aquaculture (Husen and Sharma, 2014). Once the fish are anaesthetised, their bodies relax, and stress caused by stimuli from the external environment is limited. Additionally, anaesthesia permits shortening the time required for manipulations and minimises their negative impacts such as mechanical injury or mortality following manipulation. In aquaculture, anaesthetics are used during transport, sorting, tagging, periodic reviews, monitoring breeding, and many other manipulations (Mundey and Wilson, 1997; Ross and Ross, 1999; Velisek et al., 2011; Kristan et al., 2012).

*Corresponding author; E-mail: m.rozynski@infish.com.pl; Phone: 0048 (89) 524-1071; Fax: 0048 (89) 524-0505 
The use of chemical anaesthetics in aquaculture is strictly controlled primarily to ensure their safe and effective application (Taylor and Roberts, 1999). Anaesthetics used in rearing pikeperch (Sander lucioperca) include etomidate (Propiscin), clove oil, and MS-222 (Kristan et al., 2014). Propiscin is an anaesthetic that was developed at the Inland Fisheries Institute in Olsztyn, Poland (IFI Olsztyn). It contains a $0.2 \%$ stabilised solution of etomidate (Kazun and Siwicki, 2012). Etomidate quickly induces general anaesthesia in fish with a subsequent short recovery period. Since this anaesthetic does not have a significant impact on fish physiology, it is viewed as a substance of low toxicity and insignificant side effects (Kazuń and Siwicki, 2012). Etomidate is used fairly widely to induce general anaesthesia in fish in experimental aquaculture (Hajek and Kłyszejko, 2004). It is often used in research work focusing on the controlled reproduction and rearing of pikeperch in recirculating aquaculture systems (RAS) (Zakęs et al., 2013). The recommended dose for pikeperch is $1-2 \mathrm{ml} \mathrm{l}^{-1}$ water (Szkudlarek and Zakęś, 1996; Zakęś et al., 2013). However, current knowledge on the impact of Propiscin on the haematological and biochemical parameters of pikeperch reared in RAS (health status and/or wellbeing) is incomplete. Additionally, it is not known if this anaesthetic is fully physiologically safe for this species.

Etomidate minimises the negative impacts of manipulation (mechanical injury and stress) on fish, but it can cause certain changes in haematological and blood biochemical parameters (Lepic et al., 2014). Determining the impact of exposure time and dose on pikeperch haematological and blood biochemical parameters was justified in the light of its application in pikeperch reproduction and rearing in RAS.

\section{Materials and methods}

The study material was obtained from out-of-season pikeperch reproduction and rearing larval and juvenile stages in RAS. In the current study, an experimental RAS prototype was used that included 200-1 rearing tanks and a biological filter filled with RK BioElements (RK Plast, Denmark) (Z. Zakęś, unpublished data). During the rearing of the juvenile stages [body weight $(\mathrm{W})>100 \mathrm{~g}$ ], the water parameters in the RAS were maintained as follows: temperature $21.7^{\circ} \mathrm{C}$ (range $20.7-22.6^{\circ} \mathrm{C}$ ); $\mathrm{pH} 8.24$ (range 8.22-8.26); oxygen concentration at rearing tank outflows $7.1 \mathrm{mg} \mathrm{O}_{2} 1^{-1}$ (range 7.0-7.2 $\mathrm{mg} \mathrm{O}_{2} 1^{-1}$ ); concentrations of total ammonia nitrogen $\left(\mathrm{TAN}=\mathrm{NH}_{4}{ }^{+}-\mathrm{N}+\mathrm{NH}_{3}-\mathrm{N}\right)$ and nitrite $\left(\mathrm{NO}_{2}\right)$ at the outflows $0.034 \mathrm{mg} \mathrm{TAN}{ }^{-1}$ and $0.002 \mathrm{mg} \mathrm{NO}^{-1}$. The fish were fed granulated feed $(2.5 \mathrm{~mm})$ continually for $19 \mathrm{~h} \mathrm{~d}^{-1}(09: 00-04: 00)$ with an E-1P Stella (Skretting, Norway) automated band feeder. The feed composition was $47.0 \%$ protein, $14.0 \%$ lipids, and $21.0 \%$ carbohydrates.

The fish were not fed for $24 \mathrm{~h}$ prior to the experiment. Fish with a mean body length (Lc) of $25.9 \mathrm{~cm}$ and body weight (W) of $189.89 \mathrm{~g}$ were divided into 
eight experimental groups and one control group. Each group comprised seven specimens $(n=7)$ (Table 1$)$. The specimens were placed in plastic containers with a volume of 801 , each filled with water from the RAS at the intakes to the rearing tanks in which the fish were held. During the test, the water parameters were as follows: temperature $21.3{ }^{\circ} \mathrm{C}$; oxygen concentration $7.2 \mathrm{mg} \mathrm{O}_{2} \mathrm{I}^{-1}$; water $\mathrm{pH}$ 8.2; electrolytic conductivity $380 \mu \mathrm{S} \mathrm{cm}^{-1}$; overall water hardness $170 \mathrm{mg}$ $\mathrm{CaCO}_{3} \mathrm{l}^{-1}$. The fish were subjected to either short-term $(2 \mathrm{~min})$ or long-term (10 $\mathrm{min}$ ) anaesthesia at two different doses of Propiscin containing a $0.2 \%$ stabilised solution of etomidate (IFI Olsztyn, Poland; Kazuń and Siwicki, 2001) of 1 or $2 \mathrm{ml} \mathrm{l}^{-1}$ (Table 1). Blood for haematological and biochemical analyses was collected from the four experimental groups immediately after exposure to the anaesthetic $(0 \mathrm{~h})$. Each fish was anaesthetised individually. After blood had been drawn from one specimen, a subsequent specimen was removed from the rearing tank, anaesthetised, and its blood was drawn $(\mathrm{n}=7)$. However, after anaesthesia the other four groups were moved to rearing tanks in the RAS (volume: 2001 , stocking density: $6.64 \mathrm{~kg}$ fish m $\mathrm{m}^{-3}$, water flow rate: $41 \mathrm{~min}^{-1}$, water exchange: 1.2 exchanges $\mathrm{h}^{-1}$; each group separately), and blood for haematological and biochemical analyses was collected from them after $24 \mathrm{~h}$. The control group comprised specimens from which blood was collected immediately after they had been moved to the container without the addition of any anaesthetic. The methodology of administering the anaesthetic and collecting blood samples was similar to that described in the works of Velisek et al. (2009), Velisek et al. (2011), and Kristan et al. (2012).

Table 1

Experimental setup for the application of etomidate to pikeperch $(n=7)$

\begin{tabular}{|c|c|c|c|c|c|c|c|c|c|c|}
\hline \multirow{2}{*}{ Specification } & \multirow{2}{*}{ Units } & \multirow{2}{*}{$\begin{array}{c}\text { Control } \\
\text { group }\end{array}$} & \multicolumn{8}{|c|}{ Experimental groups } \\
\hline & & & 1 & 2 & 3 & 4 & 5 & 6 & 7 & 8 \\
\hline Concentration & $\mathrm{ml} \mathrm{l}^{-1}$ & 0 & 1 & 1 & 2 & 2 & 1 & 1 & 2 & 2 \\
\hline Exposure time & $\min$ & 0 & 2 & 10 & 2 & 10 & 2 & 10 & 2 & 10 \\
\hline Sampling & $\mathrm{h}$ & 0 & 0 & 0 & 0 & 0 & 24 & 24 & 24 & 24 \\
\hline
\end{tabular}

Approximately $2 \mathrm{ml}$ of blood was drawn directly from the caudal vein using heparinised syringes. The haematological measurements of white blood cell counts (WBC), red blood cell counts (RBC), haemoglobin (HGB), haematocrit (HCT), mean corpuscular volume (MCV), mean corpuscular haemoglobin $(\mathrm{MCH})$, and mean corpuscular haemoglobin concentration (MCHC) were performed with a semi-automatic BC-2800 VET haematology analyzer (Mindray, China). After centrifugation at $4000 \mathrm{rpm}$ for $3 \mathrm{~min}$ (Fresco 17, Thermo Scientific, USA), the content of the following was determined in the serum with a BS-120 automatic biochemical analyser (Mindray, China): creatinine (CREA), total protein (TP), 
total bilirubin (BIL-T), alanine transaminase (ALT), alkaline phosphatase (ALP), calcium $\left(\mathrm{Ca}^{2+}\right)$, albumin (ALB), globulin (GLB), glucose (GLU), magnesium $\left(\mathrm{Mg}^{2+}\right)$, and ammonia $\left(\mathrm{NH}_{3}\right)$.

The results were analysed statistically with GraphPad Prism (Soft. Inc., USA). The normality of data distribution and homogeneity of variances were tested using standard procedures. Means were compared with one-way analysis of variance (ANOVA). When significant differences were found among individual experimental groups $(\mathrm{P} \leq 0.05)$, further statistical analysis was performed with the Tukey test. All values are expressed in percentages, and prior to statistical analyses, they were converted using arcsin.

\section{Results}

Full general anaesthesia was induced in the fish from all the groups as was indicated by, among other signs, the lack of defensive reflexes, a lack of eyeball movement, and lateral recumbency. No mortality linked to the anaesthetic was observed. After the fish were held in oxygenated water for 10-15 min, all specimens were roused and regained full consciousness.

Creatinine levels were significantly higher in fish exposed for $10 \mathrm{~min}$ at both doses of the anaesthetic $(\mathrm{P}<0.05)$, but after $24 \mathrm{~h}$, the values of this parameter were comparable to those of the control group $(\mathrm{P}>0.05$; Table 2$)$. Although higher levels of total protein and globulin were found in all experimental groups immediately following anaesthesia, after $24 \mathrm{~h}$ these levels were similar to those of the control group. The 10-min exposure time to the anaesthetic at both doses had a significant impact on increased glucose levels in the blood of pikeperch, but these changes reverted to previous levels after $24 \mathrm{~h}$. Similarly, levels of calcium, magnesium and ammonia were substantially higher in the blood of the fish immediately following anaesthesia as compared to the control group $(\mathrm{P}<0.05$; Table 2).

The highest WBC count was observed in specimens that had been exposed to the anaesthetic for $10 \mathrm{~min}$ at doses of 1 and $2 \mathrm{ml} \mathrm{l}^{-1}(\mathrm{P}<0.05$; Table 3$)$. However, after $24 \mathrm{~h}$ the WBC count returned to the initial value, i.e. to that of the control group. Significantly higher values of RBC, HGB and HCT were noted at both doses in specimens subjected to long-term etomidate exposure. The values of these parameters in all groups reverted to levels comparable to those of the control group after $24 \mathrm{~h}(\mathrm{P}>0.05)$. 


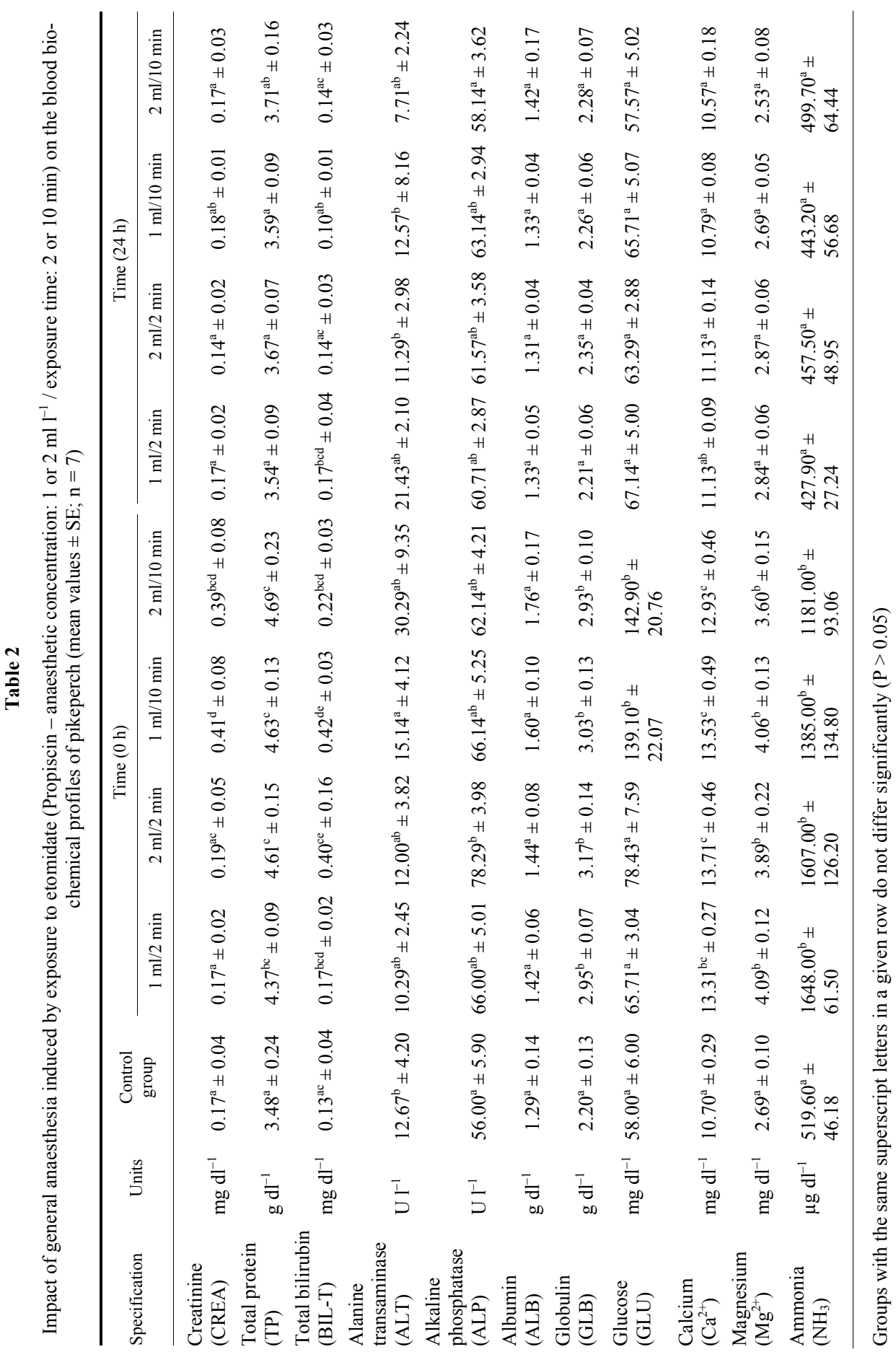




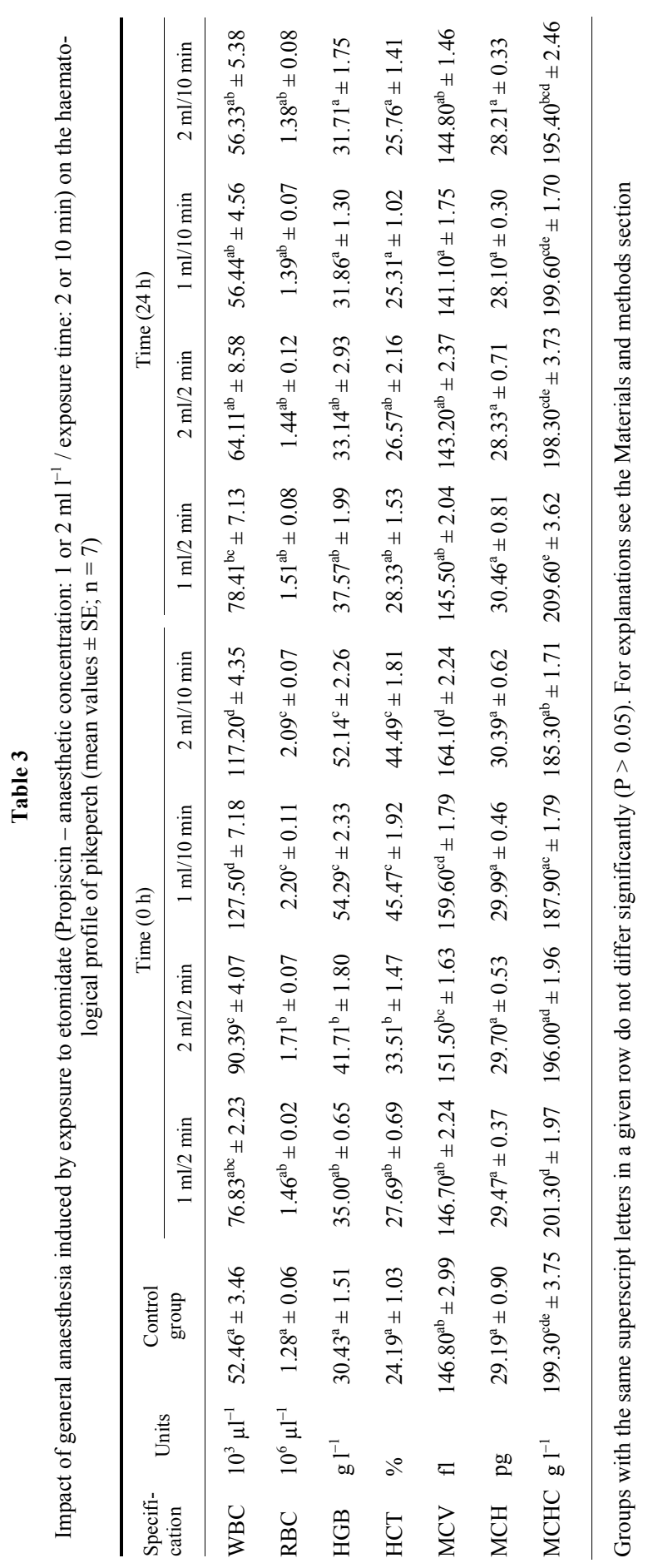




\section{Discussion}

Anaesthesia is essential during many procedures used in aquaculture, since it permits performing manipulations efficiently and minimises injuries to fish. Different fish species react differently to doses of and exposure times to anaesthetics, which is why it is important to determine the range of their impact on fish (Topić Popović et al., 2012). Haematological and blood biochemical values are used very frequently in toxicology studies (Velisek et al., 2011). The doses of Propiscin $\left(1\right.$ and $\left.2 \mathrm{ml} \mathrm{l}^{-1}\right)$ applied in this study are those recommended for pikeperch, while the exposure times ( 2 and $10 \mathrm{~min}$ ) are shorter than those permissible and/or safe for this species at a water temperature of $22^{\circ} \mathrm{C}$, which is, at a concentration of $2 \mathrm{ml}$ Propiscin $\mathrm{1}^{-1}, 15 \mathrm{~min}$ (Z. Zakęś, unpublished data). The pikeperch anaesthesia induced with Propiscin in the current study was identical to that observed in previous studies (Szkudlarek and Zakęś, 1996). In none of the anaesthetic variants tested on pikeperch $(\mathrm{W}=189.89 \mathrm{~g})$ in this study were longterm $(\geq 24 \mathrm{~h})$ changes noted in the values of blood biochemistry parameters. Although the anaesthesia caused increased contents of protein, globulin, calcium, magnesium, and ammonia in fish blood (during the 0-10 min period following exposure), the values of these parameters noted after $24 \mathrm{~h}$ were significantly lower and closer to the values demonstrated in the control group and to those determined previously for this species reared in RAS (Siwicki et al., 2003). The short-term, elevated values of total protein, globulin, calcium and magnesium noted in all pikeperch groups immediately following exposure to etomidate could indicate dehydration in the fish. Velisek et al. (2011) did not note elevated values of these parameters in rainbow trout (Oncorhynchus mykiss) $\left(1 \mathrm{ml} \mathrm{l}{ }^{-1}\right.$; exposure time $10 \mathrm{~min}$ ), nor did Mourad (2000) in carp (Cyprinus carpio) after exposure to an aqueous etomidate solution. These findings are most likely illustrations of species particularities. It is also noteworthy that Kristan et al. (2012) did not note changes in the following parameters in pikeperch exposed to etomidate (Propiscin) (1.5 $\mathrm{ml} \mathrm{l}^{-1}$; anaesthesia period $10 \mathrm{~min}$ ): glucose, total protein, albumin, globulin, alanine transaminase, alkaline phosphatase, calcium, magnesium, ammonia.

Glucose concentration increased considerably in pikeperch from both groups exposed to the etomidate solution for $10 \mathrm{~min}$. This was most likely caused by the fish bodies releasing catecholamine (adrenalin, noradrenalin and dopamine) as a result of metabolic stress (Velisek et al., 2009). Similar results were reported for vimba bream (Vimba vimba) immediately after 10-min exposure and $24 \mathrm{~h}$ later (Lepic et al., 2014), and for carp in which the level of this parameter increased significantly during anaesthesia, reaching maximum values $2 \mathrm{~h}$ after exposure (Mourad, 2000). Velisek et al. (2009) observed substantial increases in blood glucose levels of perch (Perca fluviatilis) exposed to MS-222, clove oil, and 2-phenoxyethanol for $10 \mathrm{~min}$. However, after exposure to etomi- 
date (Propiscin), they did not observe such high values of this parameter immediately following anaesthesia or $24 \mathrm{~h}$ later.

Elevated concentrations of ammonia in the blood of pikeperch from all groups immediately following exposure to etomidate could indicate increased protein catabolism and disruption in ammonia excretion (Svoboda, 2001). Velisek et al. (2009) did not observe changes in the level of this parameter when perch were exposed to etomidate (Propiscin) $\left(1 \mathrm{ml} \mathrm{l}^{-1}\right)$ for $10 \mathrm{~min}$. Similarly, Kristan et al. (2012) did not find significant changes in blood ammonia levels immediately after pikeperch exposure to etomidate; however, $24 \mathrm{~h}$ following anaesthesia the level of this compound in the blood was significantly lower than in the control group. In the current study, the ammonia levels $24 \mathrm{~h}$ after exposure were also lower in all experimental groups than in the control group; however, the differences were not statistically significant. The neutralisation of ammonia probably occurred through its transformation into non-toxic glutamine (Gomułka et al., 2014).

After anaesthesia, the WBC count in pikeperch blood increased along with the etomidate dose and exposure time, but after $24 \mathrm{~h}$ the values in all groups approached the results observed in the specimens from the control group. The intensification of stress factors and exposure to them can have a very big impact on immune system function. Kristan et al. (2012) did not observe significant decreases in WBC counts until $24 \mathrm{~h}$ after a 10 -min exposure to etomidate and to other anaesthetics tested (MS-222, clove oil, 2-phenoxyethanol). Severe stress can induce significant negative changes in WBC counts and in the functioning of the immune system. Reactions to environmental changes can even lead to leukopenia with lymphopenia, and sometimes neutrophilia (Kristan et al., 2012). Blood levels of cortisol, which is excreted in response to stress and can shorten the lifespan of lymphocytes, foster their apoptosis (Wyets et al., 1998; Verburg van Kemenade, 1999) and also reduce their proliferation (Espelid et al., 1996), can affect WBC counts. This is why lower lymphocyte counts and decreased lymphocyte activity are often observed as a stress reaction regardless of the stress factor.

Hypoxaemia, which is a reduction in the partial pressure of oxygen in the blood, is a commonly occurring phenomenon after exposure to anaesthetics (Witeska et al., 2015). Oxygen deficits can be accompanied by slow gill movements and decreased heart rates (Mourad, 2000). The values of all of the basic blood parameters (RBC, HGB, HCT) in pikeperch are observed to increase with higher doses and longer exposure times to etomidate. Mourad (2000) also noted higher values of these parameters during exposure of carp to etomidate, but this anaesthetic did not always induce haematological changes in this species (Kazun and Siwicki, 2001; Kristan et al., 2012; Lepic et al., 2014). During etomidate exposure in the current experiment, the only red blood cell parameter that changed significantly was mean corpuscular volume (MCV) immediately after exposure. In an experiment with pikeperch exposed to Propiscin (1.5 $\left.\mathrm{ml} \mathrm{l}^{-1}, 10 \mathrm{~min}\right)$, Kris- 
tan et al. (2012) observed significant changes in mean corpuscular haemoglobin concentrations; additionally, these were sustained for more than $24 \mathrm{~h}$ after anaesthesia was induced. These authors concluded that etomidate in the dose tested is not an appropriate agent for inducing general anaesthesia in pikeperch. The current study indicates, however, that all changes occurring as a result of applying this anaesthetic are reversed after $24 \mathrm{~h}$. Similarly, Lepic et al. (2014) did not observe etomidate to cause significant differences in the values of red blood cell parameters in vimba bream. It is possible that the differences detected could be linked to differences in fish condition or to differences in the chemistry of the water used during anaesthesia (Sneddon, 2012).

Taking into consideration the significant increases in some parameters following long-term exposure (10 $\mathrm{min})$ to the higher dose of etomidate (Propiscin) $\left(2 \mathrm{ml} \mathrm{l}^{-1}\right)$, one could conclude that good markers of the impact of anaesthesia on pikeperch reared in RAS are those pertaining to blood, such as levels of total protein, globulin, glucose, calcium, magnesium, and ammonia. Although short-term exposure at a lower dose of anaesthetic $\left(2 \mathrm{~min}, 1 \mathrm{ml} \mathrm{l}^{-1}\right)$ had a lesser impact on the pikeperch, all of the changes in haematological and blood biochemistry parameters noted with long-term exposure at the higher dose $\left(10 \mathrm{~min}, 2 \mathrm{ml} \mathrm{l}{ }^{-1}\right)$ were also reversed after $24 \mathrm{~h}$. This study indicates that etomidate (Propiscin) in the doses tested, i.e., 1 and $2 \mathrm{ml} \mathrm{l}^{-1}$, is a safe, effective and non-toxic anaesthetic for pikeperch, and it can be applied successfully for exposure periods of $10 \mathrm{~min}$. Propiscin used for short- and long-term manipulation can limit the impact of stress caused by many factors in pikeperch. The selection of the dose and exposure period can be made according to the requirements of manipulation (e.g., monitoring fish measurements, tagging, artificial reproduction). It is noteworthy that Propiscin can not only be used with freshwater percids, but also in marine representatives of this taxonomic fish group such as the European seabass (Dicentrarchus labrax) (Maršić-Lučić et al., 2005).

\section{Acknowledgements}

This study was conducted as part of the statutory research topic number S-028 of the Inland Fisheries Institute in Olsztyn, Poland. The authors would like to thank the two anonymous referees whose advice substantially improved the manuscript.

\section{References}

Espelid, S., Lokken, G. B., Steiro, K. and Bogwald, J. (1996): Effects of cortisol and stress on the immune system in Atlantic salmon (Salmo salar L.). Fish Shellfish Immun. 6, 95-110.

Gomułka, P., Własow, T., Szczepkowski, M., Misiewicz, L. and Ziomek, E. (2014): The effect of propofol anaesthesia on haematological and biochemical blood profile of European whitefish. Turk. J. Fish. Aquat. Sci. 14, 331-337. 
Hajek, G. and Kłyszejko, B. (2004): The effects of Propiscin (etomidate) on the behaviour, heart rate, and ventilation of common carp, Cyprinus carpio L. Acta Ichthyol. Piscat. 34, 129-143.

Husen, A. and Sharma, S. (2014): Efficacy of anesthetics for reducing stress in fish during aquaculture practices - a review. KUSET 10, 104-123.

Kazuń, K. and Siwicki, A. K. (2001): The use of Propiscin for general anaesthesia and transport of fish [in Polish]. Wydawnictwo IRS, Poland.

Kazuń, K. and Siwicki, A. K. (2012): Propiscin - a safe new anesthetic for fish. Arch. Pol. Fish. 20, 173-177.

Kristan, J., Stara, A., Polgesek, M., Drasovean, A., Kolarova, J., Priborsky, J., Blecha, M., Svacina, P., Policar, T. and Velisek, J. (2014): Efficacy of different anaesthetics for pikeperch (Sander lucioperca L.) in relation to water temperature. Neuroendocrinol. Lett. 35, 81-85.

Kristan, J., Stara, A., Turek, J., Policar, T. and Velisek, J. (2012): Comparison of the effects of four anaesthetics on haematological and blood biochemical profiles in pikeperch (Sander lucioperca L.). Neuroendocrinol. Lett. 33 (3), 66-71.

Lepic, P., Stara, A., Turek, J., Kozak, P. and Velisek, J. (2014): The effects of four anaesthetics on haematological and blood biochemical profiles in vimba bream, Vimba vimba. Vet. Med-Czech. 59, 81-87.

Maršić-Lučić, J., Mladineo, I. and Tudor, M. (2005): Comparative effectiveness of 2-phenoxyethanol and Propiscin as anesthetics for juvenile sea bass Dicentrarchus labrax L. Aquac. Int. 13, 543-553.

Mourad, M. M. (2000): Propiscin as a new anaesthetic for fish: its effects on heart activity and some haematological aspects of carp, Cyprinus carpio. Alex. J. Agric. Res. 45, 9-19.

Mundey, P. L. and Wilson, S. K. (1997): Comparative efficacy of clove oil and other chemicals in anaesthetisation of Pomacentrus amboinensis, a coral reef fish. J. Fish Biol. 51, 931-938.

Ross, L. G. and Ross, B. (1999): Anaesthetic and Sedative Techniques for Aquatic Animals. Second Edition. Blackwell Science Ltd., Oxford. 159 pp.

Siwicki, A. K., Zakęś, Z., Trapkowska, S., Kowalska, A., Kazuń, K. and Głąbski, E. (2003): Selected hematological and biochemical parameters of pikeperch Sander lucioperca (L.) from intensive culture. Arch. Pol. Fish. 11, 17-22.

Sneddon, L. U. (2012): Clinical Anesthesia and Analgesia in Fish. J. Exot. Pet Med. 21, 32-43.

Svoboda, M. (2001): Stress in fish - review. Bulletin Research Institute of Fish Culture and Hydrobiology Vodňany 37, 169-191.

Szkudlarek, M. and Zakęś, Z. (1996): Using Propiscin to induce general anesthesia in pikeperch (Stizostedion lucioperca L.) [in Polish]. Komun. Ryb. 6, 7-8.

Taylor, P. W. and Roberts, S. D. (1999): Clove oil: An alternative anaesthetic for aquaculture. N. Am. J. Aquac. 61, 150-155.

Topić Popović, N., Strunjak-Perović, I., Čož-Rakovac, R., Barišić, J., Jadan, J., Persin Berakovic, A. and Sauerborn Klobučar, R. (2012): Tricaine methane-sulfonate (MS-222) application in fish anaesthesia. J. Appl. Ichthyol. 28, 553-564.

Velisek, J., Stara, A., Li, Z., Silovska, S. and Turek, J. (2011): Comparison of the effects of four anaesthetics on blood biochemical profiles and oxidative stress biomarkers in rainbow trout. Aquaculture 310, 369-375.

Velisek, J., Stejskal, V., Kourril, J. and Svobodová, Z. (2009): Comparison of the effects of four anaesthetics on biochemical blood profiles of perch. Aquac. Res. 40, 354-361.

Verburg van Kemenade, B. M., Nowak, B., Engelsma, M. Y. and Wyets, F. A. (1999): Differential effects of cortisol on apoptosis and proliferation of carp B-lymphocytes from head kidney, spleen and blood. Fish Shellfish Immun. 9, 405-415.

Witeska, M., Dudyk, J. and Jarkiewicz, N. (2015): Haematological effects of 2-phenoxyethanol and etomidate in carp (Cyprinus carpio L.). Vet. Anaesth. Analg. 42, 537-546.

Wyets, F. A., Flikt, G. and Verburg van Kemenade, B. M. (1998): Cortisol inhibits apoptosis in carp neutrophilic granulocytes. Dev. Comp. Immunol. 22, 563-572.

Zakęś, Z., Szczepkowski, M., Partyka, K. and Wunderlich, K. (2013): Effect of gonadotropin hormonal stimulation on out-of-season propagation success of different year classes of indoorreared pikeperch [Sander lucioperca (L.)]. Aquac. Int. 21, 801-810. 